\title{
ENVIRONMENTAL CONTROLS ON ORGANIC MATTER PRODUCTION AND TRANSPORT ACROSS SURFACE- SUBSURFACE AND GEOCHEMICAL BOUNDARIES IN THE EDWARDS AQUIFER, TEXAS, USA
}

\author{
VPLIV OKOLJA NA PRODUKCIJO IN TRANSPORT ORGANSKIH \\ SNOVI: PRIMER VODONOSNIKA EDWARDS, TEXAS, ZDA
}

\author{
Benjamin T. HUTCHINS ${ }^{1}$, Benjamin F. SCHWARTZ ${ }^{1}$ \& Annette S. ENGEL ${ }^{2}$
}

\begin{abstract}
UDC 543.38:556.33(736.4

Benjamin T. Hutchins, Benjamin F. Schwartz \& Annette S. Engel: Environmental controls on organic matter production and transport across surface-subsurface and geochemical boundaries in the Edwards aquifer, Texas, USA

Karst aquifer phreatic zones are energy limited habitats supported by organic matter (OM) flow across physical and geochemical boundaries. Photosynthetic OM enters the Edwards Aquifer of Central Texas via streams sinking along its northeastern border. The southeastern boundary is marked by a rapid transition between oxygenated freshwaters and anoxic saline waters where OM is likely produced by chemolithoautotrophic microbes. Spatial and temporal heterogeneity in OM composition at these boundaries was investigated using isotopic and geochemical analyses. $\delta^{13} \mathrm{C}$ values for stream fine particulate OM (FPOM) (-33.34\% to $-11.47 \%$ ) decreased during regional drought between fall 2010 and spring $2012(\mathrm{p}<0.001)$, and were positively related to FPOM C:N ratios $\left(r^{2}=0.47\right.$, $\mathrm{p}<0.001$ ), possibly due to an increasing contribution of periphyton. Along the freshwater-saline water interface (FWSWI), $\delta^{13} \mathrm{C}_{\mathrm{FPOM}}$ values $\left(-7.23 \%\right.$ o to $-58.18 \%$ ) correlated to $\delta^{13} \mathrm{C}$ values for dissolved inorganic carbon $\left(\delta^{13} \mathrm{C}_{\text {DIC }}\right)(-0.55 \%$ o to $-7.91 \%$ ) $\left(\mathrm{r}^{2}=0.33, \mathrm{p}=0.005\right)$ and were depleted relative to $\delta^{13} \mathrm{C}_{\mathrm{DIC}}$ values by $28.44 \%$, similar to fractionation values attributed to chemolithoautotrophic carbon fixation pathways using DIC as the substrate. $\delta^{13} \mathrm{C}_{\mathrm{FPOM}}$ values also became enriched through time $(\mathrm{p}<0.001)$, and $\delta^{13} \mathrm{C}_{\text {DIC }}$ values $\left(\mathrm{r}^{2}=0.43, \mathrm{p}<0.001\right)$ and $\delta^{13} \mathrm{C}_{\mathrm{FPOM}}$ values $\left(\mathrm{r}^{2}=0.35, \mathrm{p}=0.004\right)$ at FWSWI sites increased with distance along the southwest-northeast flowpath of the aquifer. Spatial variability in FWSWI $\delta^{13} \mathrm{C}_{\text {DIC }}$ values is likely due to variable sources of acidity driving carbonate dissolution, and the temporal relationship is explained by changes to recharge and aquifer level that affected transport of chemolithoautotrophic OM across the FWSWI.

Keywords: Carbon stable isotopes, spatial and temporal variability, chemolithoautotrophic production, allochthonous input, karst.
\end{abstract}

Izvleček

UDK 543.38:556.33(736.4

Benjamin T. Hutchins, Benjamin F. Schwartz \& Annette S. Engel: Vpliv okolja na produkcijo in transport organskih snovi: Primer vodonosnika Edwards, Texas, ZDA

Zalite cone kraških vodonosnikov so energijsko revni habitati, ki jih oskrbuje tok organske snovi skozi fizične in geokemične meje. Za jugozahodno mejo obravnavanega področja je značilen hiter prehod med dobro prezračeno sladkimi vodami in anoksičnimi slanimi vodami, kjer organska snov proizvajajo kemolitoavtotrofni mikrobi. Ćasovno in prostorsko porazdeljenost organskih snovi ob teh mejah, smo raziskovali z izotopskimi in geokemičnimi analizami. Vrednosti $\delta^{13} \mathrm{C}$ za suspendirano organsko snov (FPOM) ( $-33,34 \%$ do $-11,47 \%$ ), so v sušnem obdobju, med jesenjo 2010 in pomladjo 2012, upadale $(\mathrm{p}<0.01)$ zaradi naraščajočega prispevka perifitona. Na meji med sladko in slano vodo, so vrednosti $\delta^{13} \mathrm{C}_{\mathrm{FPOM}}$ $\left(-7,23 \%\right.$ do $-58,18 \%$ o) korelirane $\mathrm{z}$ vrednostmi $\delta^{13} \mathrm{C} \mathrm{v}$ raztopljenem anorganskem ogljiku, $\delta^{13} \mathrm{C}_{\mathrm{DIC}}$, ki so med $-0,55 \%$ o in $-7,91 \%$ o $\left(r^{2}=0,33, p=0,005\right)$. Vendar je $\delta^{13} C_{F P O M}$ osiromašen glede na $\delta^{13} \mathrm{C}_{\text {DIC }}$ za $28,44 \%$, kar ustreza izotopski frakcionaciji pri pretvorbi DIC v organski ogljik v kemolitoavtotrofnih procesih. Vrednosti $\delta^{13} \mathrm{C}_{\mathrm{FPOM}}$ so naraščale s časom $(\mathrm{p}<0.001)$. Tako $\delta^{13} \mathrm{C}_{\mathrm{DIC}}\left(\mathrm{r}^{2}=0,43, \mathrm{p}<0,001\right)$, kot tudi $\delta^{13} \mathrm{C}_{\mathrm{FPOM}}\left(\mathrm{r}^{2}=0,35\right.$, $\mathrm{p}=0,004)$ ob meji med sladko in slano vodo naraščata vzdolž toka podzemne vode v smeri jugozahod-severovzhod. Prostorska spremenljivost $\delta^{13} \mathrm{C}_{\mathrm{DIC}}$ ob meji med sladko in slano vodo, je verjetno posledica spremenljivih izvorov kislosti, ki povzroča raztapljanje karbonatov. Časovno spremenljivost pa povezujemo $\mathrm{z}$ spremenljivostjo napajanja in vodostaja $\mathrm{v}$ vodonosniku, ki vplivata na prenos kemolitoavtotrofne organske snovi preko meje med sladko in slano vodo.

Ključne besede: Stabilni izotopi ogljika, prostorska in časovna spremenljivost, kemolitoavtotrofna produkcija, alogeni vnos, kras.

${ }^{1}$ Texas State University-San Marcos Department of Biology, 601 University Drive, San Marcos, TX 78666, Benjamin T. Hutching (bh1333@txstate.edu), Benjamin F. Schwartz, e-mail: bs37@txstate.edu

2 The University of Tennessee-Knoxville Department of Earth and Planetary Sciences, 1412 Circle Drive, Knoxville, TN 37996, \& Annette S. Engel, e-mail: aengel1@utk.edu

Received/Prejeto: 18.1.2013 


\section{INTRODUCTION}

The phreatic zone of karst aquifers can support diverse metazoan communities (stygobionts). In fact, some of the most diverse subterranean assemblages yet documented are recorded from extensive phreatic groundwater systems (Culver \& Pipan 2009). However, karst aquifers are considered to be nutrient-poor, and aquifer assemblages are dependent on organic matter (OM) produced photosynthetically and imported into the subterranean realm via recharging water, gravity, animals (Poulson \& Lavoie 2000; Poulson 2005), and plant root exudates (Jasinska et al. 1996), or produced in-situ through chemolithoautotrophy (Sarbu et al. 1996; Pohlman 1997). Consequently, in systems dependent on photosynthetic OM, stygobiont diversity should be predominately focused at the surfacesubsurface interface. But, the quantity and quality of $\mathrm{OM}$ entering karst aquifers via recharges change as a function of the seasonality of $\mathrm{C} 3$ and $\mathrm{C} 4$ plant communities on the surface, as well as benthic stream periphyton production along spatial and seasonal precipitation gradients (Bird et al. 1998; Artman et al. 2003; Silva et al. 2012). These differences can influence stygobiont distribution, such that if surface recharge contributions diminish seasonally or over a long period of time due to aquifer evolution, then insitu OM sources become prevalent and stygobionts may be found at redox gradients between oxidizing and reducing waters in chemolithoautotrophic systems. There has been limited research to investigate $\mathrm{OM}$ heterogeneity along redox gradients in chemolithoautotrophic aquifer systems, although geochemical gradients move vertically (Humphreys et al. 2012), and potentially laterally (Perez 1986). Therefore, to understand how OM controls the distribution and diversity of stygobionts in karst aquifers, as well as establishes groundwater food webs, more research is needed at the groundwater basin scale (Simon et al. 2007).

The Edwards Aquifer of Central Texas is one of the most prolific karst aquifers in the world (Lindgren et al. 2004) and the sole source of drinking water for nearly two million people (Johnson et al. 2009) (Fig. 1). The regional climate is sub-tropical humid, with average annual precipitation ranging from $610 \mathrm{~mm}$ in the west to $914 \mathrm{~mm}$ in the east (Nielson-Gammon 2008). Precipitation primarily occurs in spring, and potentially in the fall coinciding with tree leaf drop-off (Short et al. 1984). Recharge (and input of photosynthetic $\mathrm{OM}$ ) to the aquifer predominantly occurs by streams, fed by karstic groundwater from the adjacent Trinity Aquifer, that cross exposed limestone in the recharge zone (Fig. 1). Crossformational flow from the Trinity Aquifer (Gary et al. 2011 and references therein) is also important, but the nature of OM from this source is not known. South and west of the recharge zone, Edwards limestones are con- fined below non-karstic rocks that prevent input of allochthonous OM. In this confined portion of the aquifer, the southwestern boundary of freshwater is marked by a rapid transition between oxygenated, low total dissolved solids (TDS) waters and dysoxic to anoxic, high TDS waters that contain variably high levels of reduced compounds, including sulfides and ammonia. Six distinct geochemical facies in the saline waters (Oetting et al. 1996) correlate to changes in microbial communities (Gray \& Engel 2013) and OM characteristics (Birdwell \& Engel 2009). Several lines of evidence suggest that this zone is dominated by chemolithoautotrophic production (Birdwell \& Engel 2009; Gray \& Engel 2013). Chemolithoautotrophic production in this part of the aquifer is independent of terrestrial inputs and the habitat is buffered against seasonal geochemical changes (i.e. changes in water temperature, discharge, conductivity, etc.).

In the last three decades, widely available and inexpensive methods to analyze stable carbon isotope ratios and carbon $(\mathrm{C})$ : nitrogen $(\mathrm{N})$ ratios in $\mathrm{OM}$ have contributed to studies of OM origins, OM fluxes, food web structure, and the growth and fitness of consumers (Bukovinsky et al. 2012). Because of enzymatic discrimination against the heavier isotope of carbon $\left({ }^{13} \mathrm{C}\right)$ and isotopically distinct inorganic carbon sources, different carbon fixation pathways result in $\mathrm{OM}$ with distinct carbon isotope compositions $\left(\delta^{13} \mathrm{C}\right)$ including $\delta^{13} \mathrm{C}_{\text {terrestrial C3 plants }}=-22$ to $-32 \%, \delta^{13} \mathrm{C}_{\text {terrestrial C4 plants }}=-9$ to $-16 \%$, and $\delta^{13} \mathrm{C}_{\text {chemolithoautotrophic organic matter }}=-35$ to $<$ $-50 \%$ (Sarbu et al. 1996; Opsahl \& Chanton 2006; Finlay \& Kendall 2007; van Dover 2007). In surface aquatic systems, carbon isotopes have been successfully used to quantify the relative contributions of C3 and C4 plants (Stribling \& Cornwell 1997), and in subterranean systems, isotopic data have been used to differentiate between photosynthetic and chemolithoautotrophic OM (Sarbu et al. 1996).

As part of an ongoing investigation of food web dynamics in the Edwards Aquifer, OM at both the surface-subsurface and freshwater-saline water interface (FWSWI) was isotopically analyzed in a geochemical and environmental framework to quantify spatial and temporal changes and to test the following hypotheses related to OM sources:

(H1) the $\mathrm{C}$ isotope composition of $\mathrm{OM}\left(\delta^{13} \mathrm{C}_{\mathrm{OM}}\right)$ in recharge streams would become progressively less negative along the northeast to southwest precipitation gradient, reflecting a decrease in the relative proportion of C3 plants;

(H2) FWSWI $\delta^{13} \mathrm{C}_{\mathrm{FPOM}}$ values would be more negative than stream $\delta^{13} \mathrm{C}_{\mathrm{FPOM}}$ values, reflecting a greater 


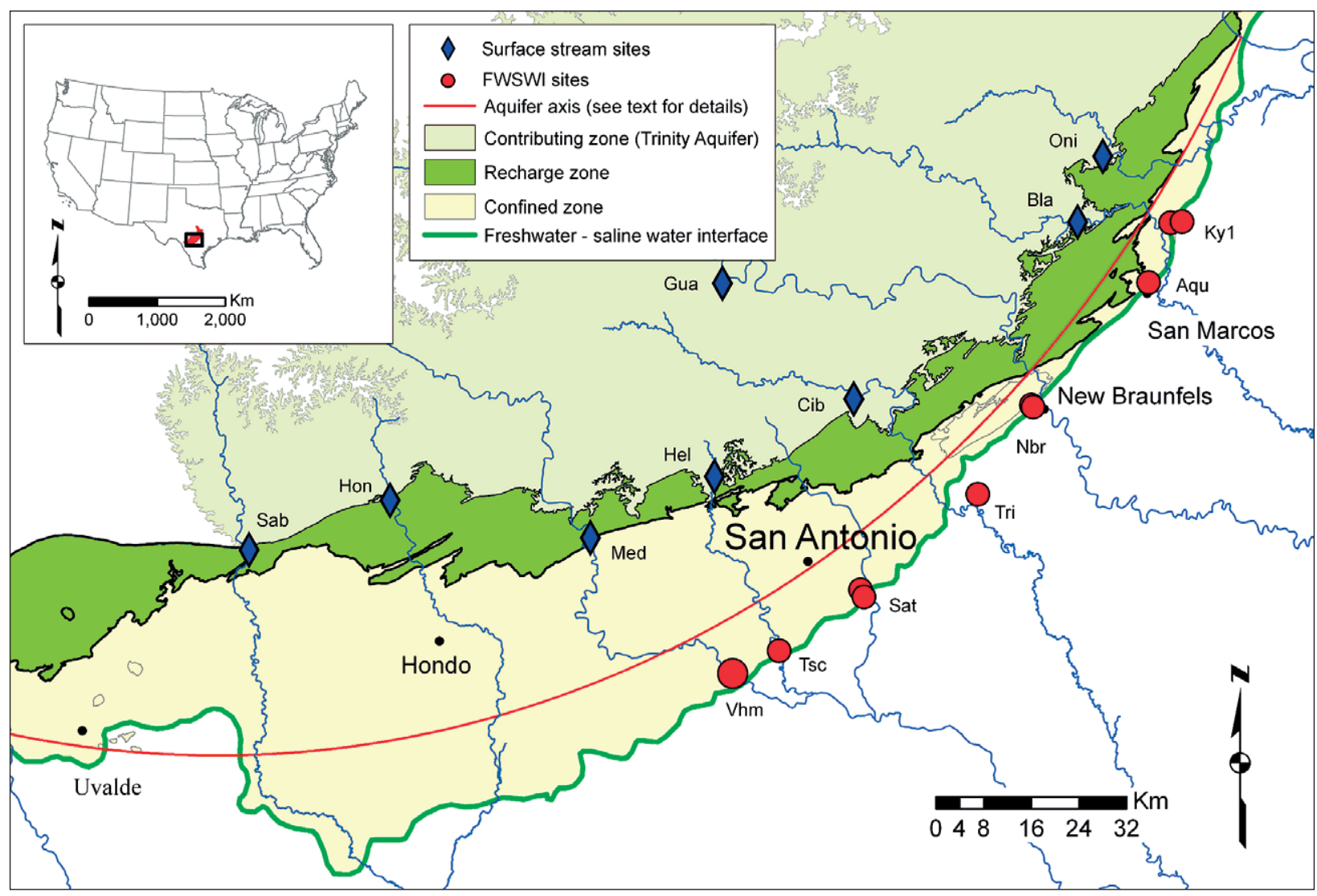

Fig. 1: The Edwards Aquifer, formed in Cretaceous limestone, extends in a $400 \mathrm{~km}$ arc that varies from 4 to $56 \mathrm{~km}$ wide and 137 to $335 \mathrm{~m}$ thick. Uplift of the Edwards Plateau during the late Cretaceous and downwarping of the Gulf of Mexico during the early Cenozoic led to exposure of Edwards formation limestones at the northern and western boundary of the aquifer (recharge zones) along west-east and southwest-northeast trending en echelon faults (Barker et al. 1994). Recharge stream sampling sites occur in or northwest of the recharge zone. Freshwater-saline water interface sampling sites occur along the freshwater-saline water interface. SAB =Sabinal Rv.; Hon = Hondo Cr.; Med = Medina Rv.; Hel = Helotes Cr.; Gua = Guadalupe Rv.; Bla = Blanco Rv.; Oni = Onion Cr.; Vhm = Verstuyft Home Farm well; Tsc = Tschirhart well; Sat = San Antonio transect wells 1 \& 2; Tri = Tri-County 2 well; Nbr = Paradise Alley Shallow; Girl Scout Shallow; and Girl Scout Deep wells; Aqu = Aquarena well; Kyl = Kyle transect wells 1 \& 2.

contribution of chemolithoautotrophic production, and values would vary across the study area, reflecting regional differences in $\delta^{13} \mathrm{C}_{\text {DIC }}$ values (the substrate for chemolithoautotrophic production);

(H3) Recharge stream $\delta^{13} \mathrm{C}_{\mathrm{OM}}$ values and $\mathrm{C}: \mathrm{N}$ ratios would decrease in the summer, reflecting a greater relative contribution of riparian C3 plants and periphyton during the dry season; and
(H4) FWSWI $\delta^{13} \mathrm{C}_{\mathrm{FPOM}}$ values and FPOM C:N values would remain constant over time, reflecting a decoupling between surface seasonality and chemolithoautotrophic production.

The results from this study provide additional evidence for both photosynthetic and chemolithoautotrophic OM in the Edwards Aquifer. More generally, this research identifies potential drivers of spatial and temporal variability in both sources.

\section{MATERIALS \& METHODS}

\section{FIELD SAMPLING AND GEOCHEMICAL ANALYSES}

Seven surface streams crossing the Edwards Aquifer recharge zone and 11 wells along the FWSWI (Fig. 1) were sampled between one and six times between 3 November 2010 and 29 March 2012 (streams) and between 16 April 2011 and 2 April 2012 (wells). The sampling period was marked by declining aquifer levels and declining stream 


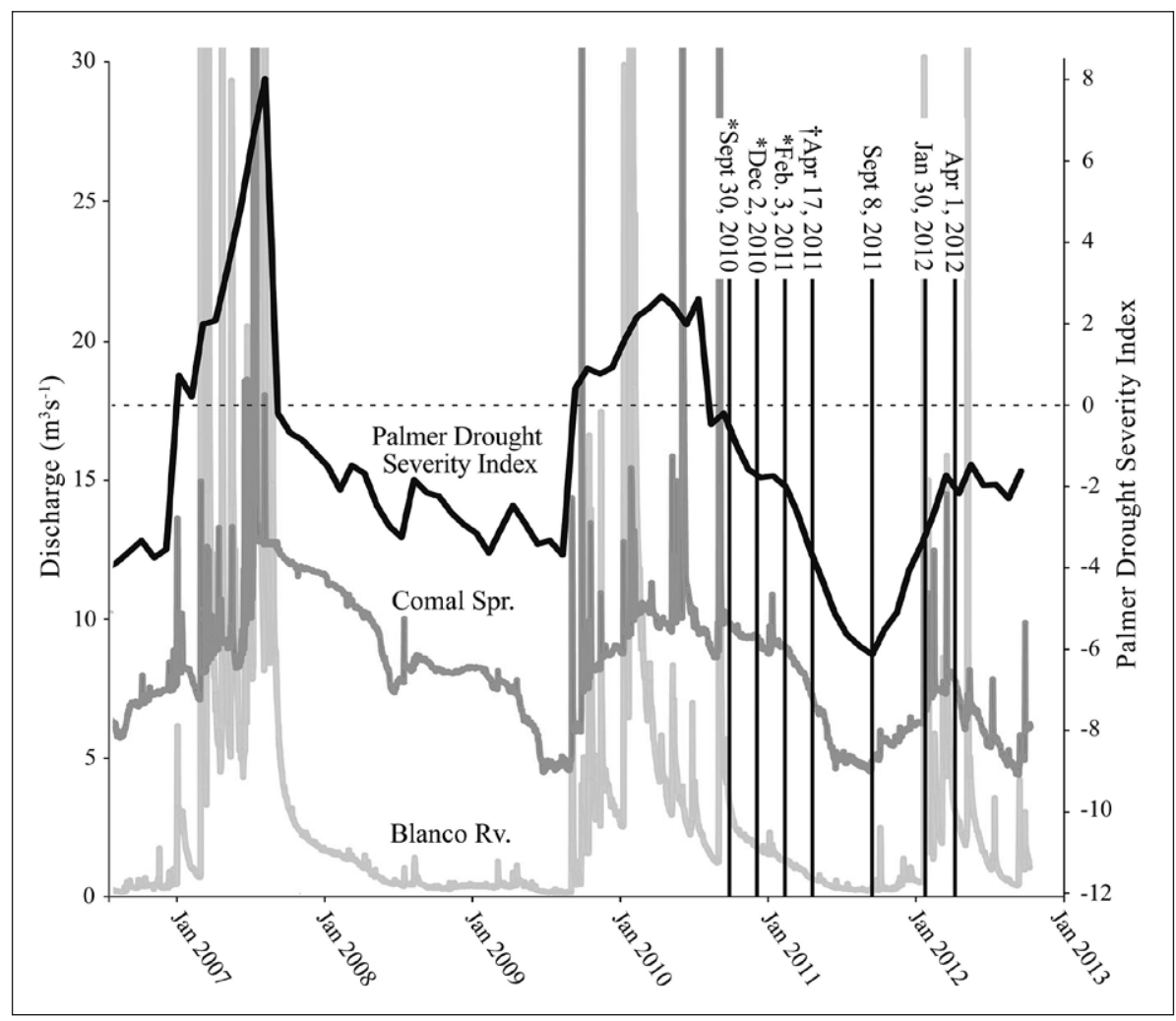

Fig. 2: Hydrographs for Comal Springs (the largest Edwards Aquifer spring) (dark grey) and Blanco River (a major source of recharge) (light grey), and Palmer Drought Severity Index (PDSI) (black) values for Division 6, Edwards Plateau (as defined by the National Climate Data Center), January 2005 to January, 2013. Sampling events are shown by black vertical bars. * indicates stream sampling only. † indicates FWSWI site sampling only. Dashed horizontal line is $P D S I=0$, representing normal conditions.

and spring flows (Fig. 2), corresponding to a period of prolonged regional drought. Palmer Drought Severity Index (PDSI) data for the Edwards Plateau were obtained from the National Oceanic and Atmospheric Administration, through the Climate Prediction Center (www. ncdc.noaa.gov/) to verify regional water imbalance based on precipitation and soil moisture supply (Palmer 1965). PDSI values above zero correspond to wetter than normal conditions, values below zero indicate drier than normal conditions, and values below -4 indicate extreme drought.

In recharge streams, $\mathrm{FPOM}$ and coarse particulate organic matter $(\mathrm{CPOM})$ were collected in $8 \mathrm{~L}$ of unfiltered water in sterile carboys after lightly disturbing the benthos by walking back and forth approximately $7 \mathrm{~m}$ upstream of the collection site. The benthos was disturbed to better represent benthic OM that enters the aquifer during storm events and via downwelling. Periphyton was collected from cobbles using the methods of Saito et al. (2007), in which three cobbles each from a riffle, run, and pool were scrubbed in the lab using a nylon brush to remove attached periphyton. At FWSWI wells (Fig. 1), two to three well volumes were purged, and physicochemistry was monitored for constituent stability before collecting $8 \mathrm{~L}$ of unfiltered water in sterile carboys. Samples were stored in the dark on ice until filtration in the lab. FPOM, CPOM, and periphyton were filtered onto $0.7 \mu \mathrm{m}$, pre-combusted Whatman glass fi- ber filters for isotopic analysis. Filters were fumigated with $\mathrm{HCl}$ for 12 to $24 \mathrm{hrs}$ and dried at $\sim 45^{\circ} \mathrm{C}$.

Temperature, dissolved oxygen (DO), $\mathrm{pH}$, and electrical conductivity (conductivity) were recorded with an In-Situ Inc. Troll 9500 multi-parameter probe with optical DO sensor (accuracy $= \pm 0.1 \mathrm{mg} / \mathrm{L}$ at $0-8 \mathrm{mg} / \mathrm{L}$ $\mathrm{DO}$ and $\pm 0.2 \mathrm{mg} / \mathrm{L}$ at $>8 \mathrm{mg} / \mathrm{L} \mathrm{DO}$ ). Sulfide and ammonia concentrations were measured with a CHEMetrics ${ }^{\circ} \mathrm{V}-2000$ Multi-analyte photometer via the methylene blue and salicylate methods, respectively. If sulfide concentration was above the detection limit $(0.2 \mathrm{mg} / \mathrm{L})$, sulfate concentration was also measured in the field colorimetrically using the turbidimetric method. This was done to avoid erroneously high laboratory sulfate concentration measurements (see below) resulting from abiotic sulfide oxidation. Additional water samples for ion chromatography and for $\delta^{18} \mathrm{O}$ and $\delta \mathrm{D}$ determination were collected and filtered through $0.45 \mu \mathrm{m}$ Fisherbrand nylon syringe filters. In the lab, dissolved ion concentrations were measured using Dionex ICS-1600 ion chromatographs (Bannockburn, IL). Alkalinity as total titratable bases dominated by bicarbonate was measured via end-point titration with $1.6 \mathrm{~N}$ sulfuric acid. $\delta^{18} \mathrm{O}$ and $\delta \mathrm{D}$ in liquid water were measured on a Los Gatos Research Liquid Water Isotope Analyzer (Mountain View, CA).

Water samples for analysis of $\delta^{13} \mathrm{C}_{\mathrm{DIC}}$ and $\delta^{13} \mathrm{C}$ of dissolved organic carbon $\left(\delta^{13} \mathrm{C}_{\mathrm{DOC}}\right)$ were collected and poisoned with $15 \mathrm{mM}$ sodium azide and stored in glass 
vials with butyl rubber septa (Doctor et al. 2008). Carbon isotope analysis was conducted at the UC Davis Stable Isotope Facility using an O.I. Analytical Model 1030
TOC Analyzer (OI Analytical, College Station, TX) interfaced to a PDZ Europa 20-20 isotope ratio mass spectrometer (Sercon Ltd., Cheshire, UK).

\section{ESTIMATION OF MEAN $\delta^{13} \mathrm{C}_{\text {FPOM }}$ FOR RECHARGE STREAMS}

The mean carbon isotope composition of FPOM entering the aquifer via recharging streams $\left(\delta^{13} \hat{\mathrm{C}}_{\mathrm{FPOM}}\right)$ was estimated using Bayesian modeling and isotope values weighted by discharge. This approach allows uncertainty in $\delta^{13} \hat{\mathrm{C}}_{\mathrm{FPOM}}$ to be quantified by treating each FPOM isotope measurement, $c_{i}$, as a sample from a separate normal distribution with separate means, $\mu_{i}$, and a common precision, $\tau_{0}$ (Eq. 1). Uninformative priors were given for $\mu_{i}$ and $\tau_{0}$ (Eq. $2-3$ ).

$$
\begin{aligned}
& c_{i} \sim N\left(\mu_{i}, \tau_{0}\right) \\
& \mu_{i} \sim N\left(0,1 e^{-6}\right) \\
& \tau_{0} \sim \operatorname{gamma}(0.001,0.001)
\end{aligned}
$$

Each isotopic value was weighted by daily average stream discharge $p_{i}$ calculated as a proportion of the sum of all daily discharge measurements $\mathrm{q}_{\mathrm{i}}$ of all streams throughout the study period (Eq. 4). Discharge values were obtained from the nearest United States Geological Survey gauging

$$
p_{i}=\frac{q_{i}}{\sum_{i=1}^{538} q_{i}}
$$

stations on the sampled streams. The parameter $c_{i}$ was estimated for all unsampled days between the first and last sampling events by linear interpolation between $c_{i}$ values. The posterior probability distribution for $\delta^{13} \hat{\mathrm{C}}_{\mathrm{FPOM}}$ (Eq. 5) was estimated using a Markov Chain Monte Carlo (MCMC) procedure.

$$
\delta^{13} \hat{C}_{F P O M}=\sum_{i=1}^{538} q_{i} * p_{i}
$$

Two MCMC chains were run, each with 500,000 iterations, a thinning rate of 50 and a burn-in of 1000 . Plots of parameter estimates as a function of MCMC iteration were assessed for adequate burn in, and convergence was assessed using Gelman and Ruben potential scale reduction factors (Gelman \& Ruben 1992). MCMC chains were run in $\mathrm{R}$ v2.15 using the rjags package (Plummer 2010).

\section{STATISTICAL ANALYSIS}

Simple linear regressions were used to test for spatial differences in $\delta^{13} \mathrm{C}_{\mathrm{FPOM}}$ and $\delta^{13} \mathrm{C}_{\mathrm{DIC}}$ values in streams and FWSWI sites ( $\mathrm{H} 1 \& \mathrm{H} 2)$. Spatial data for sampling sites were assigned in ArcMap 10.0. A curved polyline extending between the southwest and northeast margins of the aquifer (approximating the general northwest-southwest direction of groundwater flow) was created using the arc tool. The polyline was converted into 806 points spaced $0.38 \mathrm{~km}$ apart from one another and sequentially numbered, beginning with one, at the southwest end. Sampling sites were assigned a whole number location value corresponding to the number of the nearest point. For FWSWI sites, nested linear models were run to assess relationships between $\delta^{13} \mathrm{C}_{\text {DIC }}$ values and location, conductivity, and the interaction between location and conductivity. Conductivity was log transformed for normality and the relative fit of models was assessed using Akaike Information Criterion (AIC) for finite samples. Conduc- tivity was not used as a covariate for regressions of stream $\delta^{13} \mathrm{C}_{\mathrm{FPOM}}$ values against location. Stream $\delta^{13} \mathrm{C}_{\mathrm{FPOM}}$ values were square-root transformed for normality.

To quantify differences in $\mathrm{OM}$ in streams versus FWSWI sites, analyses of covariance (ANCOVA) were used to test for differences in $\delta^{13} \mathrm{C}_{\mathrm{DOC}}$ and $\delta^{13} \mathrm{C}_{\mathrm{FPOM}}$ values between stream and FWSWI samples, controlling for date as a confounding variable $(\mathrm{H} 2)$. To elucidate potential influences (e.g., origins and processing) on the $\delta^{13} \mathrm{C}$ of OM in both streams and FWSWI sites, simple linear regressions were used to test for relationships between $\delta^{13} \mathrm{C}_{\mathrm{FPOM}}$ values and $\delta^{13} \mathrm{C}_{\mathrm{DIC}}$ values $(\mathrm{H} 2)$ and between $\delta^{13} \mathrm{C}_{\mathrm{FPOM}}$ values and FPOM C:N ratios (H3). C:N ratios were $\log$ transformed. A matrix of Pearson's productmoment correlation coefficients for isotopic and physicochemical data was visually assessed for additional, potentially significant correlations (H2). Analysis of variance (ANOVA) was used to test for differences in $\delta^{13} \mathrm{C}$ of 
different fractions of $\mathrm{OM}$ in recharge streams (FPOM, CPOM, DOC, and periphyton) (H3), and a two-sided unpaired Student's $\mathrm{t}$-test was used to test for differences in $\delta^{13} \mathrm{C}$ of different fractions of OM at FWSWI sites (FPOM and DOC) (H4). Stream OM $\delta^{13} \mathrm{C}$ values were raised to the 0.3 power for normality.

To test for temporal changes in 1) $\delta^{13} \mathrm{C}_{\mathrm{FPOM}}$ values in both streams and FWSWI sites, 2) C:N ratios in recharge streams, and 3) $\delta^{13} \mathrm{C}_{\mathrm{DIC}}$ values in FWSWI sites, linear mixed effect models were employed, grouping data by sampling site (H3 and $\mathrm{H} 4)$. Four recharge streams and three groundwater sites that were each sampled four or more times were used in the analysis. Additional sites were sampled but excluded because of small sample size. $\mathrm{C}: \mathrm{N}$ ratios were log transformed and adjusted $\mathrm{r}^{2}$ values were calculated by treating each site-specific regression as a simple linear regression with a single covariate.

All statistical analyses were conducted in R v2.15 (R Core Team 2012). Mixed effects models were run using the nlme package (Pinheiro et al. 2009). False discovery rate due to multiple comparisons was controlled by adjusting $\alpha$ using the method of Benjamini \& Hochberg (1995). Sixteen statistical analyses were performed (Tab. 1), and significance was set to $\alpha=0.03$. For clarity, test statistics are not included in text but are listed in table 1.

Tab. 1: Summary of statistical tests of predictions. 1: See text for hypotheses. ${ }^{*}$ denotes statistically significant results.

\begin{tabular}{|c|c|c|c|c|c|c|c|}
\hline Hypotheses ${ }^{1}$ & Null predictions & Statistical analysis & For t & $\mathrm{N}$ & df & $\mathrm{p}$ & $r^{2}$ \\
\hline 1 & Stream $\delta^{13} \mathrm{C}-\mathrm{DIC}$ is not related to location & simple linear regression & 1.74 & 30 & $1 \& 28$ & 0.198 & 0.03 \\
\hline 1 & Stream $\delta^{13} \mathrm{C}-\mathrm{FPOM}$ is not related to location & simple linear regression & 5.96 & 26 & $1 \& 24$ & $0.022^{*}$ & 0.17 \\
\hline $1 \& 3$ & Stream $\delta^{13} \mathrm{C}-\mathrm{FPOM}$ and $\delta^{13} \mathrm{C}-\mathrm{DIC}$ are not related & simple linear regression & 0.62 & 24 & $1 \& 22$ & 0.439 & -0.02 \\
\hline $1 \& 2$ & Stream and FWSWI $\delta^{13} \mathrm{C}-\mathrm{DOC}$ does not differ & ANCOVA & 0.73 & 38 & 1 & 0.399 & NA \\
\hline $1 \& 2$ & Stream and FWSWI $\delta^{13} \mathrm{C}-\mathrm{FPOM}$ does not differ & ANCOVA & 10.16 & 46 & 1 & $0.003^{*}$ & NA \\
\hline 2 & FWSWI $\delta^{13} \mathrm{C}-\mathrm{DIC}$ is not related to location & simple linear regression & 20.17 & 26 & $1 \& 24$ & $<0.001^{*}$ & 0.43 \\
\hline 2 & FWSWI $\delta^{13} \mathrm{C}-\mathrm{FPOM}$ is not related to location & simple linear regression & 11.19 & 20 & $1 \& 18$ & $0.004^{*}$ & 0.35 \\
\hline 2 & FWSWI $\delta^{13} \mathrm{C}-\mathrm{FPOM}$ and $\delta^{13} \mathrm{C}-\mathrm{DIC}$ are not related & simple linear regression & 10.42 & 20 & $1 \& 18$ & $0.005^{*}$ & 0.33 \\
\hline 2 & FWSWI $\delta^{13} C-F P O M$ and FPOM C:N are not related & simple linear regression & 0.41 & 7 & $1 \& 5$ & 0.552 & -0.11 \\
\hline 3 & Stream $\delta^{13} \mathrm{C}-\mathrm{OM}$ fractions do not differ & ANOVA & 2.66 & 89 & $3 \& 85$ & 0.053 & NA \\
\hline 3 & Stream $\delta^{13} \mathrm{C}-\mathrm{FPOM}$ does not change with time & linear mixed effect model & 4.02 & 19 & 14 & $<0.001^{*}$ & 0.01 to 0.98 \\
\hline 3 & Stream FPOM C:N does not change with time & linear mixed effect model & 2.72 & 17 & 12 & $0.019^{*}$ & 0.14 to 0.75 \\
\hline 3 & Stream $\delta^{13} \mathrm{C}-\mathrm{FPOM}$ and FPOM C:N are not related & simple linear regression & 18.70 & 21 & $1 \& 19$ & $<0.001^{*}$ & 0.47 \\
\hline 4 & FWSWI $\delta^{13} \mathrm{C}-\mathrm{FPOM}$ and $\delta^{13} \mathrm{C}-\mathrm{DOC}$ do not differ & $t$ test & 2.44 & 44 & 28.577 & $0.021^{*}$ & NA \\
\hline 4 & FWSWI $\delta^{13} \mathrm{C}$ FPOM does not change with time & linear mixed effect model & 4.48 & 12 & 8 & $0.002^{*}$ & -0.03 to 0.96 \\
\hline 4 & FWSWI $\delta^{13} \mathrm{C}$-DIC does not change with time & linear mixed effect model & 0.16 & 18 & 13 & 0.874 & NA \\
\hline
\end{tabular}

\section{RESULTS}

During the 16-month study, 24 samples were collected from recharge streams and 32 samples were collected from FWSWI sites (Fig. 1). Stream flow varied between $0 \mathrm{~m}^{3} \mathrm{~s}^{-1}$ and $73.1 \mathrm{~m}^{3} \mathrm{~s}^{-1}$ over the course of the entire study period (Fig. 2). However, during individual sampling events, streams always had detectible flows (Fig. 2). Sampling corresponded to a period of declining stream and spring flows during the summer of 2011 and a period of increasing stream and spring flows in the fall and winter of 2011 and 2012 (Fig. 2). PDSI values ranged from wetter than normal conditions prior to July 2010 through declining values indicative of drought conditions throughout 2011 and 2012. The most severe drought condition recorded was in August 2011, which corresponded to lowest discharge for the Blanco River and Comal Springs (Fig. 2). The mean of the posterior probability distribution for the estimate of $\delta^{13} \mathrm{C}_{\mathrm{FPOM}}$ in recharging streams weighted by discharge was $-21.75 \%$ (95\% equal-tail credible interval $=-23.39 \%$ to $-20.13 \%$ ), and was similar to the unweighted analytical average value $(-24.22 \%$ )

FWSWI sites had 5.1\%o higher $\delta^{13} \mathrm{C}_{\mathrm{DIC}}$ values, $8.76 \%$ lower $\delta^{13} \mathrm{C}_{\mathrm{FPOM}}$ values, and 2.6 X lower FPOM C:N ratios than streams (Fig. 3). The average FPOM C:N ratio was 3.3 (range $=1.85$ to 5.17 ) at FWSWI sites and 8.6 (range $=2.14$ to 33.70$)$ at streams. $\delta^{13} C_{\text {DOC }}$ values were not significantly different between streams and FWSWI sites (Tab. 1). However, on average, DOC concentrations were $5 \mathrm{X}$ lower at FWSWI sites $(1.0 \mathrm{mg} / \mathrm{L}$; range $=0.5$ to $3.1 \mathrm{mg} / \mathrm{L})$ than streams $(5.0 \mathrm{mg} / \mathrm{L}$; range $=1.2$ to $13.6 \mathrm{mg} / \mathrm{L})$, and $75 \%$ of 


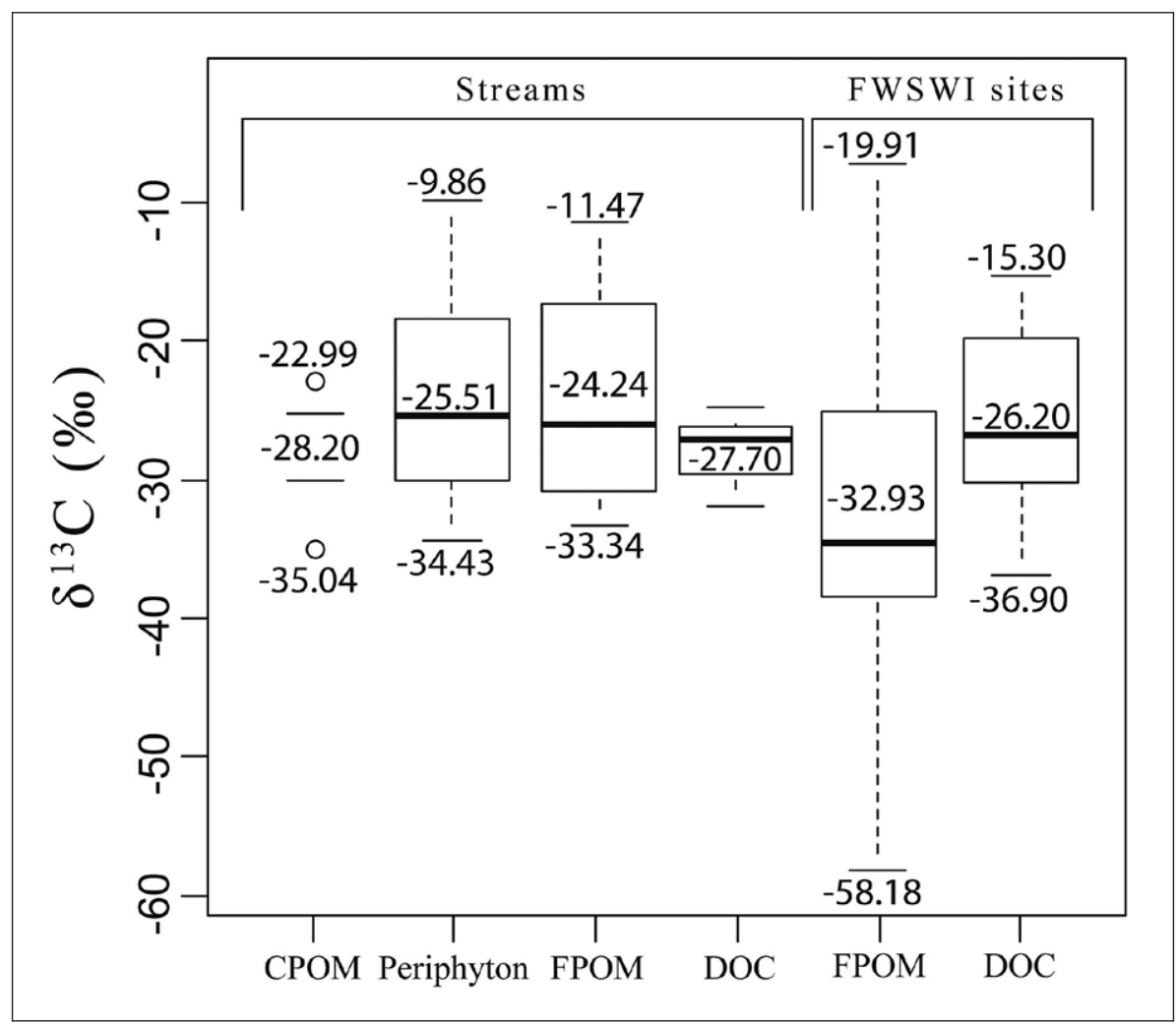

Fig. 3: Boxplots for $\delta^{13} \mathrm{C}$ values for different sampled OM fractions at stream and B. FWSWI sites.

FWSWI DOC concentrations were below the minimum concentrations of the analytical facility's calibration standards $(1.1 \mathrm{mg} / \mathrm{L})$.

In streams, $\delta^{13} \mathrm{C}$ values for CPOM, FPOM, periphyton, and DOC were not significantly different (Tab. 1 ; Fig. 3 ), and $\delta 13 \mathrm{C}_{\mathrm{FPOM}}$ values were not correlated with $\delta^{13} \mathrm{C}_{\mathrm{DIC}}$ values (Fig. 4D). A significant relationship between $\delta^{13} \mathrm{C}_{\text {Fिом }}$ values and $\mathrm{C}: \mathrm{N}$ ratios was observed in streams (Fig. 4A), but no correlations were observed between $\delta^{13} \mathrm{C}_{\mathrm{FPOM}}$ and ion concentrations or physicochemistry (Pearson's $r<0.2$ ). Stream $\delta^{13} C_{F P O M}$ values increased from the southwest to the northeast (Fig. 4C), but $\delta^{13} C_{\text {DIC }}$ values in streams were not correlated with location (Fig. 4B). Visual examination of $\delta^{13} C_{\text {periphyton }}$ data did not reveal a spatial pattern, but a relationship was not statistically assessed because, unlike allochthonous OM, we had no reason a priori to expect the isotopic composition of periphyton to vary spatially.

At FWSWI sites, $\delta^{13} \mathrm{C}_{\mathrm{FPOM}}$ values were significantly more negative than $\delta^{13} \mathrm{C}_{\mathrm{DOC}}$ values by $6.71 \%$ (Tab. 1 ), and a significant positive relationship between $\delta^{13} \mathrm{C}_{\mathrm{FPOM}}$ and $\delta^{13} \mathrm{C}_{\text {DIC }}$ values was observed (Tab. 1; Fig. $4 \mathrm{~F}$ ), with the average $\delta^{13} \mathrm{C}_{\mathrm{FPOM}}$ value being $28.44 \%$ lower than the average $\delta^{13} C_{\text {DIC }}$ value. No relationship between $\delta^{13} \mathrm{C}_{\mathrm{FPOM}}$ values and $\mathrm{C}: \mathrm{N}$ ratios was observed at FWSWI sites, although sample size was small (Tab. 1; Fig. 4E). At FWSWI sites, strong correlations were observed between $\delta^{13} \mathrm{C}_{\text {DIC }}$ values, conductivity and concentrations of several dissolved ions, including sulfide, ammonia, chloride, sulfate, lithium, sodium, potassium, magnesium, and calcium $(\mathrm{r}>0.70)$, but not between $\delta^{13} \mathrm{C}_{\text {DIC }}$ values/ conductivity and other physicochemistry measurements ( $\mathrm{pH}$, temperature, $\delta \mathrm{D}, \delta^{18} \mathrm{O}$, manganese, barium, fluoride, nitrite, and nitrate concentrations) $(\mathrm{r}<0.5)$. At FWSWI sites, both $\delta^{13} \mathrm{C}_{\text {DIC }}$ values (at sites with conductivity $<4000 \mu \mathrm{S} / \mathrm{cm}$ ) and $\delta^{13} \mathrm{C}_{\mathrm{FPOM}}$ values increased from southwest to northeast (Tab. 1; Fig. 4G-H). AIC strongly suggested that a linear model incorporating location, log conductivity, and an interaction term was substantially more likely than nested models (AIC weight $>>1$ ); all parameters were significant.

Temporal changes in $\delta^{13} \mathrm{C}_{\mathrm{FPOM}}$ values were observed at both recharge streams and FWSWI sites. Stream $\delta^{13} \mathrm{C}_{\mathrm{FPOM}}$ values increased between 30 September 2010 and 20 March 2012, although the strength of the relationship varied greatly among streams $\left(r^{2}=0.01\right.$ to 0.98 ) (Tab. 1; Fig. 5). This decrease did not correspond directly with stream discharge or PDSI, as the last two sampling events (late January and late March, 2012) followed precipitations events that resulted in increased flow in all sampled streams (Fig. 2). Visual assessment of CPOM and periphyton isotopic compositions did not indicate temporal patterns. FPOM C:N ratios in streams exhibited a weaker, but significant, negative relationship with time (Tab. 1). Unexpectedly, at FWSWI sites, $\delta^{13} C_{\text {FPOM }}$ values increased between 16 April 2011 




Fig. 4: Regressions for stream sites $(A-D)$ and FWSWI sites $(E-H)$ of $A$ and $D: \delta^{13} C_{F P O M}$ values against FPOM C:N ratios; $B$ and $F: \delta^{13} C_{F P O M}$ values against $\delta^{13} C-D I C$ values; $C$ and $G$ : $\delta^{13} C-F P O M$ values versus distance along the Edwards Aquifer flowpath; D: $\delta^{13} C-D I C$ values versus distance; and $H$ : $\delta^{13} C-D I C$ values versus distance and conductivity (multiple regression surface). All isotope values are reported in per mil (\%o). Trendlines are shown for significant regressions. $* \delta^{13} C-D I C=$ $-66.165+0.082$ distance +7.808 $\log ($ conductivity $) \quad-0.010$ distance $\log$ (conductivity) 


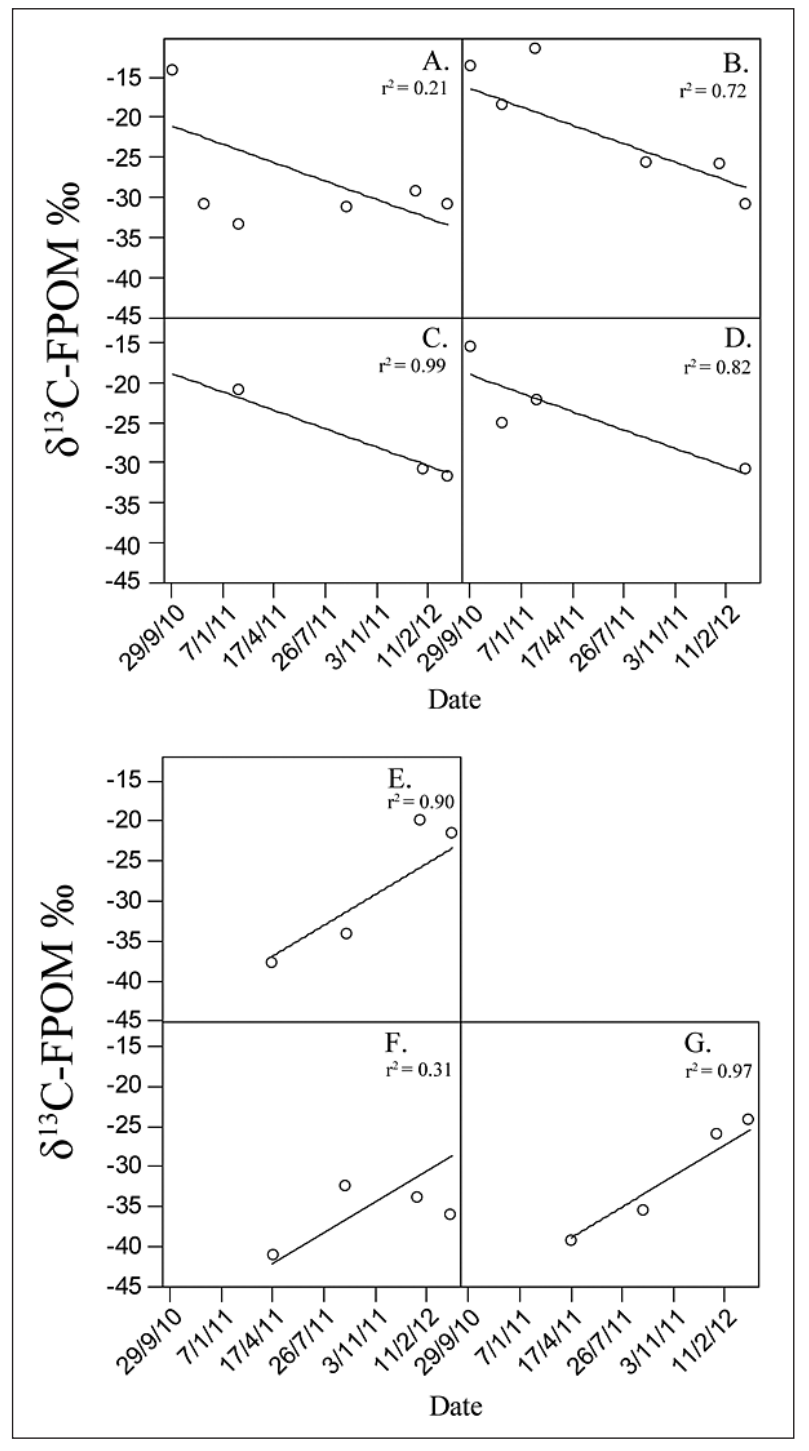

and 2 April 2012. Again, the strength of the relationship varied between sites $\left(\mathrm{r}^{2}=-0.03\right.$ to 0.96$)$ (Tab. 1 ; Fig. 5). $\delta^{13} \mathrm{C}_{\text {DIC }}$ values at FWSWI sites showed no temporal trend (Tab. 1).

Fig. 5: Results of linear mixed effects models for $\delta^{13} C-F P O M$ values versus time for stream sites (A-D), and FWSWI sites (E-G). A. Sabinal Rv.; B. Hondo Cr.; C. Helotes Cr.; D. Blanco Rv.; E. Aquarena parking lot well; F. Girl scout deep well; G. Paradise alley well. All isotope values are reported in per mil (\%o). Note that mixed effect models assess relationships between $\delta^{13} C-F P O M$ and date using site as a grouping variable. Site-specific regressions may not be significant.

\section{DISCUSSION}

The distribution and diversity of karst aquifer metazoan communities, as well as aquifer-wide food web structure, are influenced by OM that originates from, and migrates across, physical and geochemical boundaries. Research on the factors influencing DOM variability in karst aquifer systems has been limited, with previous work suggesting that OM flux into karst groundwater varies temporally based on precipitation and OM composition in soil and epikarst dripwaters (van Beynen et al. 2000; Datry et al. 2005; Ban et al. 2008), and the relative contributions of photosynthetic and chemolithoautotrophic OM are spatially variable (Sarbu et al.1996; Opsahl \& Chanton 2006; Birdwell \& Engel 2009; Roach et al. 2011; Neisch et al. 2012). The isotopic compositions of OM in Edwards
Aquifer recharge and aquifer waters, and the spatial and temporal variability in OM sources into the aquifer, have not been previously assessed, even though they support of one of the richest stygobiont communities on Earth (Longley 1981). We hypothesized that OM sources in the Edwards Aquifer would be influenced by 1) the relative proportion of $\mathrm{C} 3$ and $\mathrm{C} 4$ plant $\mathrm{OM}$ in recharging streams that changes in response to an east-west precipitation gradient, 2) FWSWI $\delta^{13} \mathrm{C}_{\mathrm{FPOM}}$ values that reflect regional differences in $\delta^{13} C_{\text {DIC }}$ values due to chemolithoautotrophic production, 3) the importance of OM from periphyton and riparian C3 plants in recharge streams that increases during the dry season, and 4) the constant composition of OM at the FWSWI over time. 


\section{CONTRIBUTIONS OF ORGANIC MATTER FROM SURFACE RECHARGE}

Two of our hypotheses focus on the contribution of OM from recharge $(\mathrm{H} 1 \& \mathrm{H} 3)$. Numerous factors influence the relative importance of allochthonous and autochthonous $\mathrm{OM}$ in streams, including stream width and riparian cover (Vannote et al. 1980), land cover and the quantity of allochthonous input (Benfield 1997), and nutrient availability (Biggs 1995). The importance of these factors in Edwards Aquifer recharge streams is unknown, but the decrease in $\delta^{13} \mathrm{C}_{\mathrm{FPOM}}$ values and FPOM C:N ratios in recharging streams during the summer of 2011, and the negative relationship between FPOM C:N ratios and $\delta^{13} \mathrm{C}_{\text {FPOM }}$ values (Figs. 4-5) may suggest that the observed temporal isotopic shift in FPOM results from a decrease in the relative contribution of allochthonous $\mathrm{OM}$ and an increase in the relative contribution of periphyton. This shift could result from decreased allochthonous input (i.e. both $\mathrm{C} 3$ and $\mathrm{C} 4$ plants), but is not likely to result from increased in-stream productivity because $\delta^{13} \mathrm{C}_{\mathrm{FPOM}}$ minima values do not occur during spring and summer when periphyton growth is greatest (Finlay \& Kendall 2007).

Alternatively, the observed temporal pattern is consistent with a decrease in the relative contribution of C4 plants from beyond the riparian zone because of a decline in overland flows and a subsequent increase in allochthonous input from the $\mathrm{C} 3$ dominated riparian zone, as has been documented for a river in Cameroon (Bird et al. 1998). Decreasing $\delta^{13} C_{\mathrm{FPOM}}$ values in streams continued through increased flows in winter and spring of 2012, although the pattern was inconsistent among streams (Figs. $2 \& 5$ ). In particular, $\delta^{13} \mathrm{C}_{\mathrm{FPOM}}$ values from the Sabinal River changed minimally after an initial decrease after September 2010. A small increase in $\delta^{13} \mathrm{C}_{\mathrm{FPOM}}$ values in the Sabinal and Blanco Rivers corresponded to increased flow in winter and spring of 2012, but this was not observed in Helotes Creek. Spring and stream hydrographs and the PDSI show 2-3 year oscillations with wetter than normal periods corresponding to El Niño periods (Fig. 2), and the general trend of declining stream $\delta^{13} \mathrm{C}_{\mathrm{FPOM}}$ values may be linked to these longer ENSO time-scale trends in stream discharge. The rela- tively small increase in discharge in winter and spring of 2012, and the negative trend in $\delta^{13} \mathrm{C}_{\mathrm{FPOM}}$ values, were embedded within a longer drying trend, as illustrated by the PDSI values from spring of 2011 through December 2012 (Fig. 2).

Although the relationship was weak, stream $\delta^{13} \mathrm{C}_{\mathrm{FPOM}}$ values became more enriched from southwest to northeast (Tab. 1, Fig. 4), which does not support our hypothesis of increasing contributions of $\mathrm{C} 3$ plant material in the northeast. Furthermore, the lack of spatial gradients in $\delta^{13} \mathrm{C}_{\text {periphyton }}$ and $\delta^{13} \mathrm{C}_{\mathrm{DIC}}$ values, and of a significant regression between $\delta^{13} \mathrm{C}_{\mathrm{FPOM}}$ and $\delta^{13} \mathrm{C}_{\mathrm{DIC}}$ values (Tab. 1, Fig. 4), indicates that the observed spatial gradient in $\delta^{13} \mathrm{C}_{\mathrm{FPOM}}$ values is not the result of spatial differences in $\delta^{13} \mathrm{C}_{\text {periphyton }}$ values that would result from regional differences in $\delta^{13} \mathrm{C}_{\mathrm{DIC}}$ values. Rather, the observed gradient may indicate decreasing contributions of periphyton and increased contributions of terrestrial plant $\mathrm{OM}$ in the northeast, although our data do not allow for estimated proportions because of the large degree of overlap in $\delta^{13} \mathrm{C}_{\mathrm{CPOM}}$ and $\delta^{13} \mathrm{C}_{\text {periphyton }}$ values.

The estimated discharge-weighted average value for $\delta^{13} C_{\mathrm{FPOM}}$ entering streams $(-21.75 \%$ ) was similar to the unweighted average, yet the employed Bayesian method of estimation has several advantages to an unweighted analytical average. Most obviously, an unweighted analytical average can over-emphasize values collected during low recharge periods and under-emphasize values collected during high recharge periods. Secondly, this method incorporates uncertainty associated with individual isotopic measurements, allowing for calculation of $95 \%$ equal tail credible intervals. Finally, although not investigated here, the model has potential for incorporation of increased complexity. Specifically, the relationship between the amount of OM entering the aquifer and discharge could be modeled non-linearly (e.g., it may reach an asymptote at some discharge threshold), and the relationship between the amount of OM entering the aquifer and discharge could be modelled to vary among streams.

\section{CONTRIBUTIONS OF ORGANIC MATTER FROM THE FWSWI}

The juxtaposition of reduced electron donors (e.g., $\mathrm{H}_{2} \mathrm{~S}$ ) and electron acceptors (e.g., $\mathrm{O}_{2}, \mathrm{NO}_{3}^{-}$) at the FWSWI, coupled with a plentiful source of inorganic carbon source (DIC as $\mathrm{HCO}_{3}^{-}$and $\mathrm{CO}_{2}$ ) from carbonate dissolution sup- port chemolithoautotrophic metabolic processes. Pronounced differences in OM dynamics between recharge stream and FWSWI well waters were revealed through isotope analysis. $\delta^{13} \mathrm{C}_{\mathrm{FPOM}}$ values were significantly more 
negative at FWSWI sites than in recharging streams (Tab. 1, Fig. 3), which suggests strong isotopic discrimination against ${ }^{13} \mathrm{C}$ during autotrophic $\mathrm{C}$ fixation. We hypothesized that chemolithoautotrophic production occurred along the FWSWI, based on identification of putative sulfur-oxidizing microbial groups from the FWSWI (e.g., Epsilonproteobacteria, Thiothrix spp., Thiobacillus spp.) (Engel \& Randall 2011; Gray \& Engel 2013). The results support our hypothesis, and also corroborate previous findings that microbial, rather than surface (i.e. plant), humic-like, OM is present at the FWSWI (Birdwell \& Engel 2009). However, the positive relationship between $\delta^{13} \mathrm{C}_{\mathrm{FPOM}}$ and $\delta^{13} \mathrm{C}_{\mathrm{DIC}}$ at FWSWI sites (Fig. 4) illustrates that $\mathrm{C}$ isotope data alone are insufficient to quantify the relative proportions of photosynthetic and chemolithoautotrophic OM in a sample. Several factors influence the isotopic composition of chemolithoautotrophic OM, including the isotopic signature of the $\mathrm{C}$ substrate, $\mathrm{C}$ limitation (Cowie et al. 2009), C fixation rate (Laws et al. 1995), and the $C$ fixation pathway utilized (Berg et al. 2010).

The $6.71 \%$ difference between $\delta^{13} \mathrm{C}_{\mathrm{FPOM}}$ and $\delta^{13} \mathrm{C}_{\text {DOC }}$ values at FWSWI sites could be the result of several processes. Relative to DOM, POM is not transported great distances into groundwater systems ( $\mathrm{Si}$ mon et al. 2003), so FWSWI DOC may be comprised of a greater proportion of surface derived, photosynthetic OM. Alternatively, DOC may represent more processed or recalcitrant OM. In soils, preferential metabolism of ${ }^{12} \mathrm{C}$ in OM during decomposition can increase $\delta^{13} \mathrm{C}_{\mathrm{OM}}$ by 1-3\%o (Boström et al. 2007). To our knowledge, however, this has not been documented for groundwater. Lastly, the values may suggest additional $\mathrm{C}$ assimilation due to methanotrophy (Whiticar 1999). Although analysis of the spatial distribution of $\mathrm{CH}_{4}$ in the Edwards Aquifer saline zone has not been studied in detail, Zhang et al. (1998) report a positive relationship between $\mathrm{CH}_{4}$ and $\mathrm{SO}_{4}^{2-}$ concentrations in the saline zone, and we cannot rule out regional differences in $\mathrm{CH}_{4}$ concentration that could influence regional variability in FWSWI $\delta^{13} \mathrm{C}_{\mathrm{OM}}$.

Reasons for the enrichment in FWSWI $\delta^{13} \mathrm{C}_{\mathrm{FPOM}}$ values between April 2011 and March 2012 (Fig. 5) are unclear, but heterotrophic processing of OM is insufficient to account for the observed isotopic differences, as much as $18 \%$. The observed temporal changes could be the result of changing contributions of OM produced in geochemically distinct portions of the aquifer. These changes may be the result of declining aquifer levels and variability in flow along the FWSWI due to drought; however, there are currently no data to support this hypothesis.

The significant positive relationship between $\delta^{13} \mathrm{C}_{\mathrm{DIC}}$ and $\delta^{13} \mathrm{C}_{\mathrm{FPOM}}$ values (Tab. 1, Figs. 4) supports our prediction that regional differences in $\delta^{13} C_{\text {DIC }}$ values, the substrate for chemolithoautotrophic production, affect $\delta^{13} \mathrm{C}_{\mathrm{FPOM}}$ values. $\delta^{13} \mathrm{C}_{\mathrm{DIC}}$ values at FWSWI sites increased from southwest to northeast for sites with conductivity $<4000 \mu \mathrm{S} / \mathrm{cm}$ (Fig. $4 \mathrm{H}$ ) and showed no significant temporal variation. This trend mirrors patterns in stable isotopes of helium (Hunt et al. 2010), which were interpreted as evidence of increasing groundwater residence times from the southwest to northeast. Increased residence times, and subsequent increased time for rock-water interaction, can shift $\delta^{13} \mathrm{C}_{\mathrm{DIC}}$ values towards the isotopic composition of the host rock ( -2\%o for Edwards carbonates) (Ellis 1985; Gonfiantini \& Zuppi 2003).

Variable sources of acidity may also have an important role in the isotopic composition of FWSWI $\delta^{13} \mathrm{C}_{\text {DIC }}$ values. Dissolution of calcite by carbonic acid (derived from $\mathrm{CO}_{2}$ respired during decomposition of plant matter in soils and/or hyporheic zones) results in DIC with a $\delta^{13} \mathrm{C}$ value intermediate between that of the calcite and carbonic acid (Finlay 2003; Breeker et al. 2012). Dissolution of Edwards limestones by carbonic acid derived from respired $\mathrm{CO}_{2}$ will produce DIC with $\delta^{13} \mathrm{C}$ values $\sim-10 \%$ for calcite-saturated water, as well as alkalinities and $\mathrm{Ca}^{2+}$ concentrations similar to those observed in surface streams (appendix 1). However, DIC sourced from dissolution of calcite by an acid other than carbonic acid (e.g., sulfuric acid) will have an isotopic composition closer to that of the host rock, as is observed in FWSWI sites. The strong positive relationship between FWSWI $\delta^{13} \mathrm{C}_{\text {DIC }}$, conductivity (Fig. $4 \mathrm{H}$ ), and sulfide, supports the hypothesis that dissolution in low conductivity freshwaters is driven by carbonic acid, and in high conductivity saline waters (with locally high levels of sulfide $\sim 100 \mathrm{mg} / \mathrm{L}$ ), dissolution is driven by sulfuric acid derived from microbially mediated oxidation of reduced sulfur compounds (Gray \& Engel 2013).

\section{CONCLUSION}

Groundwater ecosystems can be supported, at least in part, by allochthonous OM input from the surface, whereby the composition and supply rate is temporally variable and dependent on water balance conditions at 
the surface. In streams supplying allochthonous OM to the Edwards Aquifer, $\delta^{13} \mathrm{C}_{\mathrm{FPOM}}$ values and FPOM C:N ratios decreased during and after a severe drought in 2011, suggesting a diminished contribution of terrestrial plant material (especially C4 material from beyond the riparian zone) and an increasing contribution of in-stream production. A spatial gradient in stream $\delta^{13} \mathrm{C}_{\mathrm{FPOM}}$ values due to changes in the relative abundance of $\mathrm{C} 3$ and $\mathrm{C} 4$ plants was not apparent. Weighting $\delta^{13} \mathrm{C}_{\mathrm{FPOM}}$ values for FPOM input into aquifers by recharge provides a more realistic estimate, and quantification of uncertainty around estimates is both important and straightforward using a Bayesian approach. In addition to allochthonous inputs, chemolithoautotrophy along the FWSWI is an important source of autochthonous OM, based on geochemical, microbial, and isotopic evidence. For the Edwards Aquifer, allochthonous and autochthonous OM sources were, on average, isotopically distinct, although the isotopic composition of chemolithoautotrophic OM was spatially variable and dependent on the isotopic composition of DIC. Additional research is needed to understand the degree to which the distinct OM sources are utilized by the diverse microbial and metazoan community in the Edwards Aquifer, as well as to characterize the OM geochemically (e.g., through high-resolution spatial analyses of OM isotopic composition and degree of humification). These analyses would allow for better quantification of the relative proportions of allochthonous and autochthonous $\mathrm{OM}$ throughout the aquifer.

\section{ACKNOWLEDGEMENTS}

This research was funded by the National Science Foundation (\#0742306; 1110503) the U.S. Geological Survey (\#9658-11), and the Jones Endowment for Aqueous Geochemistry at the University of Tennessee. The San Antonio Water System, The Edwards Aquifer Authority, Zara
Environmental, and several private landowners provided or facilitated access to sampling sites. Kevin Simon and an anonymous reviewer provided valuable comments during the revision of this manuscript.

\section{REFERENCES}

Artman, U., Waringer, J.A. \& M. Schagerl, 2003: Seasonal dynamics of algal biomass and allochthonous input of coarse particulate organic matter in a low-order sandstone stream (Weidlingbach, Lower Austria).Limnologica, 33, 77-91.

Ban, F., Pan, G., Zhu, J., Cai, B. \& M. Tan, 2008: Temporal and spatial variations in the discharge and dissolved organic carbon of drip waters in Beijing Shihua Cave, China.- Hydrological Processes, 22, 3749-3758.

Barker, R.A., Bush, P.W. \& E. T. Baker, Jr., 1994: Geologic History and Hydrogeologic Setting of the EdwardsTrinity Aquifer System, West-Central Texas.- United States Geological Survey, Report number: Water Resources Investigations Report 94-4039.

Benfield, E.F., 1997: Comparison of litterfall input to streams.- Journal of the North American Benthological Society, 16, 104-108.
Benjamini, Y. \& Y. Hochberg, 1995: Controlling the False Discovery Rate: A Practical and Powerful Approach to Multiple Testing.- Journal of the Royal Statistical Society, 57, 289-300.

Berg, I. A., Kockelkorn, D., Ramos-Vera, W.H., Say, R. F., Zarzycki, J., Hügler, M., Alber, B.E. \& G. Fuchs, 2010: Autotrophic carbon fixation in Archaea.- Nature Reviews Microbiology, 8: 447-460.

Biggs, B.J.F., 1995: The Contribution of Flood Disturbance, Catchment Geology and Land Use to the Habitat Template of Periphyton in Stream Ecosystems.- Freshwater Biology, 33, 419-438.

Bird, M.I., Giresse, P. \& S. Ngos, 1998: A seasonal cycle in the carbon-isotope composition of organic carbon in the Sanaga River, Cameroon.- Limnology and Oceanography, 43, 143-146. 
Birdwell, J.E. \& A.S. Engel, 2009: Variability in Terrestrial and Microbial Contributions to Dissolved Organic Matter Fluorescence in the Edwards Aquifer, Central Texas.- Journal of Cave and Karst Studies, 71, 144-156.

Boström, B., Comstedt, D. \& A. Ekblad, 2007: Isotope Fractionation and ${ }^{13} \mathrm{C}$ Enrichment in Soil Profiles During the Decomposition of Soil Organic Matter.Oecologia, 153, 89-98.

Breeker, D.O., Payne, A.E., Quade, J., Banner, J.L., Ball, C.E., Meyer, K.W. \& B.D. Cowan, 2012: The sources and sinks of $\mathrm{CO}_{2}$ in caves under mixed woodland and grassland vegetation Geochimica et Cosmochimica Acta.- 96, 230-246.

Bukovinskey, T., Verschoor, A.M., Helmsing, N.R., Bezemer, T.M. Bakker, E.S., Vos, M. \& L.N. de Senerpont Domis, 2012: The Good, the Bad and the Plenty: Interactive Effects of Food Quality and Quantity on the Growth of Different Daphnia Species.- PLOS ONE, 7, e42966.

Cowie, B.R., Slater, G.F., Bernier, L. \& L.A. Warren, 2009: Carbon Isotope Fractionation in Phospholipid Fatty Acid Biomarkers of Bacteria and Fungi Native to an Acid Mine Drainage Lake.- Organic Geochemistry, 40, 956-962.

Culver, D.C. \& T. Pipan, 2009: The Biology of Caves and Other Subterranean Habitats.- The Biology of Habitats, Oxford University Press, pp. 254, Oxford.

Datry, T., Malard, F. \& J. Gibert, 2005: Response of invertebrate assemblages to increased groundwater recharge rates in a phreatic aquifer.- Journal of the North American Benthological Society, 24: 461-477.

Doctor, D.H., Kendall, C., Sebestyen, S.D., Shanley, J.B., Ohte, N. \& E.W. Boyer, 2008: Carbon Isotope Fractionation of dissolved Inorganic Carbon (DIC) Due to Outgassing of Carbon Dioxide from a Headwater Stream.- Hydrological Processes, 22, 2410-2423.

Ellis, P. M., 1985: Diagenesis of the Lower Cretaceous Edwards Group in the Balcones Fault Zone Area, SouthCentral Texas.- PhD thesis, University of Texas at Austin, pp. 326.

Engel, A.S. \& K.W. Randall, 2011: Experimental Evidence for Microbially Mediated Carbonate Dissolution from the Saline Water Zone of the Edwards Aquifer, Central Texas.- Geomicrobiology Journal, 28: $313-327$.

Finlay, J.C., 2003: Controls of Streamwater Dissolved Inorganic Carbon Dynamics in a Forested Watershed.- Biogeochemistry, 62, 231-252.
Finlay, J.C. \& C. Kendall, 2007: Stable Isotope Tracing of Temporal and Spatial Variability in Organic Matter Sources to Freshwater Ecosystems.- In: Michener, R. \& K. Lajtha (eds.) Stable Isotopes in Ecology and Environmental Science, Blackwell Publishing, pp. 283-333, Malden.

Gary, M.O., Gary, R.H. \& B.B. Hunt (eds.), 2011: Interconnection of the Trinity (Glen Rose) and Edwards Aquifers Along the Balcones Fault Zone and Related Topics, Karst Conservation Initiative February 17, 2011 Meeting Proceedings, pp. 46, Austin.

Gelman, A. \& D.B. Rubin, 1992: Inference from Iterative Simulation Using Multiple Sequences.- Statistical Science, 7, 457-472.

Gonfiantini, R. \& G.M. Zuppi, 2003: Carbon Isotope Exchange Rate of DIC in Karst Groundwater.- Chemical Geology, 197, 319-336.

Gray, C.J. \& A.S. Engel, 2012: Microbial Diversity and Impact on Carbonate Geochemistry Across a Changing Geochemical Gradient in a Karst Aquifer.- The ISME Journal, advance online publication: $1-13$.

Humphreys, W., Tetu, S., Elbourne, L., Gillings, M., Seymour, J., Mitchell, J. \& I. Paulsen, 2012: Geochemical and Microbial Diversity of Bundera Sinkhole, an Anchialine System in the Eastern Indian Ocean.Natura Croatica, 21, 59-63.

Hunt, A.G., Lambert, R.B., Fahlquist, L. 2010: Sources of Groundwater Based on Helium Analyses in and Near the Freshwater/ Saline-Water Transition Zone of the San Antonio Segment of the Edwards Aquifer, SouthCentral Texas, 2002-03.- United States Geological Survey, Report Number: Scientific Investigations Report 2010-5030

Jasinska, E.J., Knott, B., McComb, A.J. 1996: Root Mats in Ground Water: A Fauna-Rich Cave Habitat.Journal of the North American Benthological Society, 15, 508-519.

Johnson, S., Schindel, G., \& J. Hoyt, 2009: Water Quality Trends Analysis of the San Antonio Segment, Balcones Fault Zone Edwards Aquifer, Texas.- Edwards Aquifer Authority, Report Number: 09-03.

Laws, E.A., Popp, B.N., Bidigare, R.R., Kennicutt, M.C. \& S.A. Macko, 1995: Dependence of Phytoplankton Carbon Isotopic Composition on Growth Rate and $\left[\mathrm{CO}_{2}\right]_{\mathrm{aq}}$ : Theoretical Considerations and Experimental Results.- Geochimica et Cosmochimica Acta, 59, 1131-1138. 
Lindgren, R. J., Dutton, A. R., Hovorka, S. D., Worthington, S. R. H. \& S. Painter, 2004: Conceptualization and Simulation of the Edwards Aquifer, San Antonio Region, Texas.- United States Geological Survey, Report Number: Scientific Investigations Report 2004-5277.

Neisch, J.A., Pohlman, J.W. \& T.M. Iliffe, 2012: The use of stable and radiocarbon isotopes as a method for delineating sources of organic material in anchialine systems.- Natura Croatica, 21, 83-85.

Nielsen-Gammon, J.W., 2008: The Changing Climate of Texas.- In: Schmandt, J., Clarkson, J. \& G.R. North (eds.) The Impact of Global Warming on Texas, $2^{\text {nd }}$ edition. University of Texas Press, pp. 39-68, Austin.

Oetting, G.C., Banner, J.L. \& J.M. Sharp, Jr., 1996: Regional Controls on the Geochemical Evolution of Saline Groundwaters in the Edwards Aquifer, Central Texas.- Journal of Hydrology, 181, 251-283.

Opsahl, S.P. \& J.P. Chanton, 2006: Isotopic evidence for methane-based chemosynthesis in the Upper Floridan aquifer food web.- Oecologia, 150, 89-96.

Palmer, W.C., 1965: Meteorologic drought.- U.S. Weather Bureau, Resource Paper 45.

Perez, R., 1986: Potential for Updip Movement of Saline water in the Edwards Aquifer, San Antonio, Texas. United States Geological Survey, Report Number: Water-Resources Investigations Report 86-4032.

Pinheiro, J., Bates, D., DebRoy, S. \& D. Sarkar, 2009: Linear and Nonlinear Mixed Effects Models. R package version 3,1-96.- R Foundation for Statistical Computing, Vienna.

Plummer, M., 2010: Bayesian Graphical Models Using MCMC.- R package version 2.1, 0-10.

Pohlman, J.W., Iliffe, T.M. \& L.A. Cifuentes, 1997: A Stable Isotope Study of Organic Cycling and the Ecology of an Anchialine Cave Ecosystem.- Marine Ecology Progress Series, 155, 17-27.

Poulson, T.L., 2005: Food Sources.- In: Culver, D.C. \& W.B. White (eds.) Encyclopedia of Caves. Elsevier Academic Press, pp. 255-263, Amsterdam.

Poulson, T.L. \& K.H. Lavoie, 2000: The Trophic Basis of Subsurface Ecosystems.- In: Wilkens, H., D. C. Culver \& W. F. Humphreys (eds.) Subterranean Ecosystems. Ecosystems of the World 30. Elsevier Academic Press, pp. 231-250, Amsterdam.

R Core Team, 2012: R: A Language and Environment for Statistical Computing.- R Foundation for Statistical Computing, Vienna.

Roach, K.A., Tobler, M. \& K.O. Winemiller, 2011: Hydrogen sulfide, bacteria, and fish: a unique, subterranean food chain.- Ecology, 92, 2056-2062.
Saito, L., Redd, C., Chandra, S., Atwell, L., Fritsen, C. H. \& M. R. Rosen, 2007: Quantifying Foodweb Interactions with Simultaneous Linear Equations: Stable Isotope Models of the Truckee River, USA.- Journal of the North American Benthological Society, 26, 642-662.

Sarbu, S.M., Kane, T.C. \& B. K. Kinkle, 1996: A Chemoautotrophically Based Cave Ecosystem.- Science, 272, 1953-1955.

Short, R.A., Smith, S.L., Guthrie, D.W., Stanford, J.A. 1984: Leaf litter processing rates in four Texas streams.- Journal of Freshwater Ecology, 2, 469-473.

Silva, M.S., de Oliveira Bernardi, L.F., Martins, R.P. \& R.L. Ferreira, 2012: Transport and Consumption of Organic Detritus in a Neotropical Limestone Cave.Acta Carsologica, 41, 139-150.

Simon, K.S., Benfield, E.F. \& S.A. Macko, 2003: Food Web Structure and the Role of Epilithic Biofilms in Cave Streams.- Ecology, 84, 2395-2406.

Simon, K.S., Pipan, T. \& D.C. Culver, 2007: A Conceptual Model of the Flow and Distribution of Organic Carbon in Caves.- Journal of Cave and Karst Studies, 69, 279-284.

Stribling, J.M. \& J.C. Cornwell, 1997: Identification of Important Primary Producers in a Chesapeake Bay Tidal Creek System Using Stable Isotopes of Carbon and Sulfur.- Estuaries, 20, 77-85.

van Beynen, P. v., Ford, D. \& H. Schwarcz, 2000: Seasonal variability in organic substances in surface and cave waters at Marengo Cave, Indiana.- Hydrological Processes, 14, 1177-1197.

van Dover, C.L, 2007: Stable isotope studies in marine chemoautotrophically based ecosystems: an update.- In: Michener, R. \& K. Lajtha (eds.) Stable Isotopes in Ecology and Environmental Science, Blackwell Publishing, pp. 202-237, Malden.

Vannote, R.L., Minshall, G.W., Cummins, K.W., Sedell, J.R. \& C.E. Cushing, 1980: The River Continuum Concept.- Canadian Journal of Fisheries and Aquatic Science, 37, 130-137.

Whiticar, M.J., 1999: Carbon and Hydrogen Isotope Systematics of Bacterial Formation and Oxidation of Methane.- Chemical Geology, 161, 291-314.

Zhang, C., Grossman, E.L. \& J.W. Ammerman, 1998: Factors Influencing Methane Distribution in Texas Ground Water.- Ground Water, 36, 58-66. 
Appendix 1: Physicochemical data average values (min/max) for recharge stream and FWSWI sites.

\begin{tabular}{|c|c|c|c|c|c|c|c|}
\hline \multicolumn{8}{|c|}{ Recharge Streams } \\
\hline & Sab & Hon & Med & Hel & Gua & Bla & Oni \\
\hline $\mathrm{DO}(\mathrm{mg} / \mathrm{L})$ & $\begin{array}{c}8.29 \\
(5.50 / 10.65)\end{array}$ & $\begin{array}{c}8.98 \\
(8.22 / 9.59)\end{array}$ & $\begin{array}{c}8.00 \\
(6.58 / 9.26)\end{array}$ & $\begin{array}{c}8.41 \\
(6.71 / 10.90)\end{array}$ & $\begin{array}{l}9.14 \\
\text { (na) }\end{array}$ & $\begin{array}{c}9.76 \\
(7.87 / 12.45)\end{array}$ & $\begin{array}{c}9.19 \\
(7.25 / 10.97)\end{array}$ \\
\hline $\mathrm{pH}$ & $\begin{array}{c}7.81 \\
(7.05 / 8.37)\end{array}$ & $\begin{array}{c}7.86 \\
(7.46 / 8.11)\end{array}$ & $\begin{array}{c}7.51 \\
(7.13 / 8.05)\end{array}$ & $\begin{array}{c}7.68 \\
(6.95 / 8.14)\end{array}$ & $\begin{array}{l}7.52 \\
(\mathrm{na})\end{array}$ & $\begin{array}{c}8.16 \\
(7.40 / 9.44)\end{array}$ & $\begin{array}{c}7.33 \\
(7.23 / 7.54)\end{array}$ \\
\hline $\begin{array}{l}\text { Cond } \\
(\mu \mathrm{S} / \mathrm{cm})\end{array}$ & $\begin{array}{c}405 \\
(234 / 548)\end{array}$ & $\begin{array}{c}312 \\
(297 / 320)\end{array}$ & $\begin{array}{c}411 \\
(348 / 484)\end{array}$ & $\begin{array}{c}538 \\
(434 / 693)\end{array}$ & $\begin{array}{l}349 \\
\text { (na) }\end{array}$ & $\begin{array}{c}432 \\
(358 / 504)\end{array}$ & $\begin{array}{c}445 \\
(350 / 557)\end{array}$ \\
\hline $\begin{array}{c}T \\
\left(C^{\circ}\right)\end{array}$ & $\begin{array}{c}16.42 \\
(10.02 / 26.21)\end{array}$ & $\begin{array}{c}10.69 \\
(7.88 / 15.99)\end{array}$ & $\begin{array}{c}18.20 \\
(13.24 / 24.46)\end{array}$ & $\begin{array}{c}16.69 \\
(13.12 / 22.35)\end{array}$ & $\begin{array}{l}8.17 \\
\text { (na) }\end{array}$ & $\begin{array}{c}14.74 \\
(3.68 / 21.16)\end{array}$ & $\begin{array}{c}13.26 \\
(6.45 / 21.81)\end{array}$ \\
\hline $\begin{array}{l}\delta^{13} C_{\mathrm{DIC}} \\
(\% \circ)\end{array}$ & $\begin{array}{c}-7.92 \\
(-8.56 /-7.44)\end{array}$ & $\begin{array}{c}-6.55 \\
(-6.89 /-6.21)\end{array}$ & $\begin{array}{c}-8.67 \\
(-9.34 /-7.87)\end{array}$ & $\begin{array}{c}-10.25 \\
(-10.95 /-9.03)\end{array}$ & $\begin{array}{c}-7.55 \\
(\mathrm{na})\end{array}$ & $\begin{array}{c}-8.00 \\
(-9.98 /-4.20)\end{array}$ & $\begin{array}{c}-8.88 \\
(-9.40 /-8.15)\end{array}$ \\
\hline $\begin{array}{c}\delta^{13} C_{\mathrm{poc}} \\
(\%))\end{array}$ & $\begin{array}{c}-30.0 \\
(-32.0 /-26.4)\end{array}$ & $\begin{array}{l}-25.7 \\
\text { (na) }\end{array}$ & $\begin{array}{l}\mathrm{nm} \\
(\mathrm{nm})\end{array}$ & $\begin{array}{c}-27.9 \\
(-28.6 /-27.2)\end{array}$ & $\begin{array}{l}\mathrm{nm} \\
(\mathrm{nm})\end{array}$ & $\begin{array}{c}-28.1 \\
(-30.1 /-26.4)\end{array}$ & $\mathrm{nm}(\mathrm{nm})$ \\
\hline $\begin{array}{l}\delta D \\
(\% \circ)\end{array}$ & $\begin{array}{c}-16.59 \\
(-20.76 /-11.63)\end{array}$ & $\begin{array}{c}-16.23 \\
(-22.40 /-11.83)\end{array}$ & $\begin{array}{c}-16.34 \\
(-24.38 /-10.39)\end{array}$ & $\begin{array}{c}-22.04 \\
(-35.43 /-11.71)\end{array}$ & $\begin{array}{c}-20.11 \\
\text { (na) }\end{array}$ & $\begin{array}{c}-20.66 \\
(-31.25 /-12.54)\end{array}$ & $\begin{array}{c}-26.63 \\
(-33.98 /-21.68)\end{array}$ \\
\hline $\begin{array}{l}\delta^{18} O \\
(\%))\end{array}$ & $\begin{array}{c}-2.86 \\
(-3.41 /-1.79)\end{array}$ & $\begin{array}{c}-2.26 \\
(-2.87 /-1.60)\end{array}$ & $\begin{array}{c}-2.13 \\
(-3.73 /-0.53)\end{array}$ & $\begin{array}{c}-3.03 \\
(-5.95 / 0.20)\end{array}$ & $\begin{array}{l}-2.81 \\
(\mathrm{na})\end{array}$ & $\begin{array}{c}-2.97 \\
(-5.32 /-1.38)\end{array}$ & $\begin{array}{c}-3.73 \\
(-5.47 /-1.79)\end{array}$ \\
\hline $\begin{array}{l}\text { Sulfide } \\
\text { (ppm S) }\end{array}$ & $\begin{array}{c}0.05 \\
(0.04 / 0.06)\end{array}$ & $\begin{array}{l}0.05 \\
\text { (na) }\end{array}$ & $\begin{array}{l}\mathrm{nm} \\
(\mathrm{nm})\end{array}$ & $\begin{array}{c}0.05 \\
(0.05 / 0.07)\end{array}$ & $\begin{array}{l}\mathrm{nm} \\
(\mathrm{nm})\end{array}$ & $\begin{array}{c}0.08 \\
(0.05 / 0.16)\end{array}$ & $\begin{array}{l}\mathrm{nm} \\
(\mathrm{nm})\end{array}$ \\
\hline $\begin{array}{c}\mathrm{Fl}^{-} \\
(\mathrm{ppm})\end{array}$ & $\begin{array}{c}0.16 \\
(0.15 / 0.20)\end{array}$ & $\begin{array}{c}0.20 \\
(0.19 / 0.23)\end{array}$ & $\begin{array}{c}0.18 \\
(0.17 / 0.19)\end{array}$ & $\begin{array}{c}0.11 \\
(0.09 / 0.12)\end{array}$ & $\begin{array}{l}0.24 \\
(\mathrm{na})\end{array}$ & $\begin{array}{c}0.21 \\
(0.16 / 0.30)\end{array}$ & $\begin{array}{c}0.20 \\
(0.19 / 0.22)\end{array}$ \\
\hline $\begin{array}{c}\mathrm{Cl}^{-} \\
\text {(ppm) }\end{array}$ & $\begin{array}{c}15.38 \\
(6.09 / 20.54)\end{array}$ & $\begin{array}{c}14.44 \\
(12.40 / 15.87)\end{array}$ & $\begin{array}{c}12.97 \\
(11.90 / 13.62)\end{array}$ & $\begin{array}{c}46.80 \\
(15.07 / 76.14)\end{array}$ & $\begin{array}{c}26.70 \\
\text { (na) }\end{array}$ & $\begin{array}{c}14.93 \\
(13.78 / 15.45)\end{array}$ & $\begin{array}{c}24.92 \\
(21.07 / 27.66)\end{array}$ \\
\hline $\begin{array}{l}\mathrm{NO}_{2}^{-} \\
(\mathrm{ppm})\end{array}$ & $\begin{array}{c}0.00 \\
(0.00 / 0.00)\end{array}$ & $\begin{array}{c}0.00 \\
(0.00 / 0.00)\end{array}$ & $\begin{array}{c}0.00 \\
(0.00 / 0.00)\end{array}$ & $\begin{array}{c}0.00 \\
(0.00 / 0.00)\end{array}$ & $\begin{array}{l}0.00 \\
\text { (na) }\end{array}$ & $\begin{array}{c}0.00 \\
(0.00 / 0.00)\end{array}$ & $\begin{array}{c}0.00 \\
(0.00 / 0.00)\end{array}$ \\
\hline $\begin{array}{l}\mathrm{Br}^{-} \\
(\mathrm{ppm})\end{array}$ & $\begin{array}{c}0.00 \\
(0.00 / 0.00)\end{array}$ & $\begin{array}{c}0.00 \\
(0.00 / 0.00)\end{array}$ & $\begin{array}{c}0.00 \\
(0.00 / 0.00)\end{array}$ & $\begin{array}{c}0.00 \\
(0.00 / 0.00)\end{array}$ & $\begin{array}{l}0.00 \\
\text { (na) }\end{array}$ & $\begin{array}{c}0.00 \\
(0.00 / 0.00)\end{array}$ & $\begin{array}{c}0.00 \\
(0.00 / 0.00)\end{array}$ \\
\hline $\begin{array}{l}\mathrm{NO}_{3}^{-} \\
(\mathrm{ppm})\end{array}$ & $\begin{array}{c}0.89 \\
(0.00 / 3.12)\end{array}$ & $\begin{array}{c}0.76 \\
(0.43 / 1.27)\end{array}$ & $\begin{array}{c}1.52 \\
(1.14 / 2.12)\end{array}$ & $\begin{array}{c}2.10 \\
(0.00 / 8.04)\end{array}$ & $\begin{array}{l}2.67 \\
\text { (na) }\end{array}$ & $\begin{array}{c}2.72 \\
(0.00 / 8.58)\end{array}$ & $\begin{array}{c}0.44 \\
(0.00 / 1.17)\end{array}$ \\
\hline $\begin{array}{c}\mathrm{PO}_{4}^{3-} \\
(\mathrm{ppm})\end{array}$ & $\begin{array}{c}0.00 \\
(0.00 / 0.00)\end{array}$ & $\begin{array}{c}0.00 \\
(0.00 / 0.00)\end{array}$ & $\begin{array}{c}0.00 \\
(0.00 / 0.00)\end{array}$ & $\begin{array}{c}0.00 \\
(0.00 / 0.00)\end{array}$ & $\begin{array}{l}0.00 \\
\text { (na) }\end{array}$ & $\begin{array}{c}0.00 \\
(0.00 / 0.00)\end{array}$ & $\begin{array}{c}0.00 \\
(0.00 / 0.00)\end{array}$ \\
\hline $\begin{array}{l}\mathrm{SO}_{4}^{2-} \\
(\mathrm{ppm})\end{array}$ & $\begin{array}{c}51.53 \\
(29.21 / 107.6)\end{array}$ & $\begin{array}{c}65.24 \\
(52.95 / 76.78)\end{array}$ & $\begin{array}{c}57.58 \\
(53.80 / 60.20)\end{array}$ & $\begin{array}{c}63.08 \\
(21.87 / 115.9)\end{array}$ & $\begin{array}{c}29.61 \\
\text { (na) }\end{array}$ & $\begin{array}{c}37.20 \\
(26.07 / 56.65)\end{array}$ & $\begin{array}{c}49.65 \\
(40.34 / 55.73)\end{array}$ \\
\hline $\begin{array}{l}\text { Alkalinity } \\
\text { (ppm) }\end{array}$ & $\begin{array}{c}233.29 \\
(152.79 / 295.72)\end{array}$ & $\begin{array}{c}88.71 \\
(\mathrm{na})\end{array}$ & $\begin{array}{l}\mathrm{nm} \\
(\mathrm{nm})\end{array}$ & $\begin{array}{c}194.68 \\
(192.22 / 197.15)\end{array}$ & $\begin{array}{c}256.29 \\
\text { (na) }\end{array}$ & $\begin{array}{c}156.07 \\
(88.72 / 202.08)\end{array}$ & $\begin{array}{l}\mathrm{nm} \\
(\mathrm{nm})\end{array}$ \\
\hline $\begin{array}{c}\mathrm{Li}^{+} \\
(\mathrm{ppm})\end{array}$ & $\begin{array}{c}0.00 \\
(0.00 / 0.01)\end{array}$ & $\begin{array}{c}0.00 \\
(0.00 / 0.01)\end{array}$ & $\begin{array}{c}0.00 \\
(0.00 / 0.00)\end{array}$ & $\begin{array}{c}0.00 \\
(0.00 / 0.01)\end{array}$ & $\begin{array}{l}0.00 \\
\text { (na) }\end{array}$ & $\begin{array}{c}0.00 \\
(0.00 / 0.01)\end{array}$ & $\begin{array}{c}0.00 \\
(0.00 / 0.00)\end{array}$ \\
\hline $\begin{array}{l}\mathrm{Na}^{+} \\
(\mathrm{ppm})\end{array}$ & $\begin{array}{c}8.79 \\
(5.51 / 10.77)\end{array}$ & $\begin{array}{c}10.55 \\
(9.97 / 11.56)\end{array}$ & $\begin{array}{c}7.77 \\
(7.37 / 8.15)\end{array}$ & $\begin{array}{c}19.17 \\
(8.16 / 26.14)\end{array}$ & $\begin{array}{l}15.03 \\
(\mathrm{na})\end{array}$ & $\begin{array}{c}7.48 \\
(5.51 / 8.74)\end{array}$ & $\begin{array}{c}10.08 \\
(9.17 / 11.33)\end{array}$ \\
\hline $\begin{array}{c}\mathrm{NH}_{4}^{+} \\
(\mathrm{ppm})\end{array}$ & $\begin{array}{c}0.01 \\
(0.00 / 0.09)\end{array}$ & $\begin{array}{c}0.00 \\
(0.00 / 0.00)\end{array}$ & $\begin{array}{c}0.00 \\
(0.00 / 0.00)\end{array}$ & $\begin{array}{c}0.00 \\
(0.00 / 0.00)\end{array}$ & $\begin{array}{l}0.00 \\
\text { (na) }\end{array}$ & $\begin{array}{c}0.00 \\
(0.00 / 0.03)\end{array}$ & $\begin{array}{c}0.00 \\
(0.00 / 0.00)\end{array}$ \\
\hline $\begin{array}{c}\mathrm{Ka}^{+} \\
(\mathrm{ppm})\end{array}$ & $\begin{array}{c}1.29 \\
(0.77 / 2.89)\end{array}$ & $\begin{array}{c}1.45 \\
(1.04 / 2.20)\end{array}$ & $\begin{array}{c}1.46 \\
(1.36 / 1.52)\end{array}$ & $\begin{array}{c}1.42 \\
(0.72 / 2.10)\end{array}$ & $\begin{array}{l}1.54 \\
\text { (na) }\end{array}$ & $\begin{array}{c}1.34 \\
(1.06 / 1.47)\end{array}$ & $\begin{array}{c}1.11 \\
(0.86 / 1.36)\end{array}$ \\
\hline $\begin{array}{l}\mathrm{Mg}^{2+} \\
(\mathrm{ppm})\end{array}$ & $\begin{array}{c}12.00 \\
(5.56 / 18.32)\end{array}$ & $\begin{array}{c}8.77 \\
(7.57 / 10.00)\end{array}$ & $\begin{array}{c}12.01 \\
(11.38 / 13.10)\end{array}$ & $\begin{array}{c}15.40 \\
(10.05 / 19.63)\end{array}$ & $\begin{array}{c}27.53 \\
\text { (na) }\end{array}$ & $\begin{array}{c}16.92 \\
(13.01 / 22.65)\end{array}$ & $\begin{array}{c}15.95 \\
(12.26 / 18.73)\end{array}$ \\
\hline $\begin{array}{l}\mathrm{Mn}^{2+} \\
(\mathrm{ppm})\end{array}$ & $\begin{array}{c}0.00 \\
(0.00 / 0.00)\end{array}$ & $\begin{array}{c}0.00 \\
(0.00 / 0.00)\end{array}$ & $\begin{array}{c}0.00 \\
(0.00 / 0.00)\end{array}$ & $\begin{array}{c}0.00 \\
(0.00 / 0.00)\end{array}$ & $\begin{array}{l}0.00 \\
\text { (na) }\end{array}$ & $\begin{array}{c}0.00 \\
(0.00 / 0.00)\end{array}$ & $\begin{array}{c}0.00 \\
(0.00 / 0.00)\end{array}$ \\
\hline $\begin{array}{l}\mathrm{Ca}^{2+} \\
(\mathrm{ppm})\end{array}$ & $\begin{array}{c}62.28 \\
(37.27 / 79.76)\end{array}$ & $\begin{array}{c}55.77 \\
(46.38 / 60.60)\end{array}$ & $\begin{array}{c}60.58 \\
(54.22 / 63.83)\end{array}$ & $\begin{array}{c}63.41 \\
(50.99 / 81.83)\end{array}$ & $\begin{array}{c}61.47 \\
\text { (na) }\end{array}$ & $\begin{array}{c}51.87 \\
(35.21 / 69.78)\end{array}$ & $\begin{array}{c}73.08 \\
(69.24 / 76.76)\end{array}$ \\
\hline $\begin{array}{c}\mathrm{Sr}^{2+} \\
(\mathrm{ppm})\end{array}$ & $\begin{array}{c}0.58 \\
(0.00 / 2.04)\end{array}$ & $\begin{array}{c}0.25 \\
(0.00 / 0.75)\end{array}$ & $\begin{array}{c}0.00 \\
(0.00 / 0.00)\end{array}$ & $\begin{array}{c}0.33 \\
(0.00 / 0.99)\end{array}$ & $\begin{array}{l}0.00 \\
\text { (na) }\end{array}$ & $\begin{array}{c}0.67 \\
(0.00 / 2.26)\end{array}$ & $\begin{array}{c}0.00 \\
(0.00 / 0.00)\end{array}$ \\
\hline $\begin{array}{l}\mathrm{Ba}^{2+} \\
\text { (ppm) }\end{array}$ & $\begin{array}{c}0.07 \\
(0.00 / 0.36)\end{array}$ & $\begin{array}{c}0.00 \\
(0.00 / 0.00)\end{array}$ & $\begin{array}{c}0.00 \\
(0.00 / 0.00)\end{array}$ & $\begin{array}{c}0.01 \\
(0.00 / 0.07)\end{array}$ & $\begin{array}{l}0.00 \\
\text { (na) }\end{array}$ & $\begin{array}{c}0.09 \\
(0.00 / 0.31)\end{array}$ & $\begin{array}{c}0.00 \\
(0.00 / 0.00)\end{array}$ \\
\hline
\end{tabular}


